\title{
An Analysis of Higher Education Policy Act 101 of 1997
}

\author{
C. I. Ede ${ }^{1}$, N. N. Jili ${ }^{2} \&$ F. M. Vezi-Magigaba ${ }^{3}$ \\ ${ }^{1} \mathrm{PhD}$ candidate, University of Zululand, South Africa \\ ${ }^{2}$ AHoD, Public Administration Dept., University of Zululand, South Africa \\ ${ }^{3}$ Senior Lecturer, University of Zululand, South Africa \\ Correspondence: N. N. Jili, AHoD, Public Administration Dept., University of Zululand, South Africa.
}

Received: October 15, 2021

Accepted: February 4, 2022

Online Published: February 4, 2022

doi:10.5430/ijhe.v11n7p64

URL: https://doi.org/10.5430/ijhe.v11n7p64

\begin{abstract}
The South African higher education sector is one of the most contested sectors with high policy influxes since the beginning of current democratic dispensation. From a horrendous past where it endured the repressive strategy that disenfranchised majority of the population, the country's higher education system undoubtedly needed a thorough reshape to meet the then changing national development needs and aspirations of the newly elected democratic government. Hence, the prime strategy of redressing past imbalances and inequalities accruing from pre-democratic era, was justified through Higher Education Policy (HEP) Act 101 - whose operational consistency is evident in the past twenty-five years. This synoptic review focuses on HEP Act 101 by unravelling the circumstances presaging its formation, the policy provisions and amendments - whose sectional highlights are also embodied herein. The brief prelude to the policy's penultimate silver-jubilee forms an agendum for extensive research on its performance over the last quarter-century, while the ensuing discourse aims to channel scholarly attention on critical matters that may inform a new HEP formation or amendment, that will be more agreeable with contemporary socioeconomic needs of the masses and synchronous to new national development goals in the long run.
\end{abstract}

Keywords: policies, higher education, South Africa

\section{Introduction}

Education is the hallmark of transformative development in every society. Higher education is essentially the advancer of this uncommon transformative capacity in individuals - who supposed to be development catalysts in the society where they live. This is why responsible governments take policymaking at higher education level very seriously, and the South African higher education sector boasts of ample legislative amendments to HEP 101 over its quarter-century existence. From a disjointed past during Apartheid, the transformed higher education system has been engrossed in redressing past imbalance through a "single coordinated system" (DoE 1996:1) designed to "provide optimal opportunity for learning" to all South Africans (RSA 1997a:2). The newly unified system was also charged - as per the founding goals of HEP 101 - to

"restructure and transform programmes and institutions to respond better to [national] needs; redress past discrimination and ensure representivity (sic) and equal access; promote the values which underlie an open and democratic society; respect and encourage ... academic freedom, ... speech and expression, creativity, scholarship and research, ... religion, belief and opinion; pursue excellence, promote the full realisation of the potential of every student and employee, tolerance of ideas and appreciation of diversity; contribute to the advancement of all forms of knowledge and scholarship, in keeping with international standards of academic quality; [as well as] respond to the needs of the Republic and of the communities served by the institutions" (RSA 1997a:2).

\section{Background to Higher Education Policy Act 101}

'Policy' is a general term that describes (non)governmental plans and strategies in pursuance of certain goals. It can also be defined as a set of institutionalised principles and practices guiding the furtherance of organisational goals over a period, or a statutory instrument which outlines government schemes for a sector. Public policies are mostly derived from government's resolutions (based on development needs or the ruling party's ideology), which are then set out for discussions (as Green Papers) before being drafted as proposals of a possible legislative effect (White Papers) and - upon successful passage via Parliamentary proceedings - promulgated as an 'Act' for lawful resource 
mobilisation towards its implementation. The journey of HEP 101 began with the August (1996) Report, "A Framework for Transformation" by former National Commission on Higher Education, from whence the "Green Paper on Higher Education Transformation" came on December 1, 1996. The six-chapter (63-page) document recognized the need to expand and transform higher education system in South Africa in line with emerging national development aspirations of the new government. It also acknowledged the fundamental flaws of "inequalities, imbalances and distortions ... from ... Apartheid", then proposed that the system "be reshaped to serve a new social order, ... meet pressing national needs ... and respond to a context of new realities and opportunities" (DoE 1996:1-2). In his intro to the Green Paper, the then minister of Education, Prof S.M.E. Bengu, noted:

"To address what is defective requires transformation.... For such ... transformation to be effective, ... redress must operate ... in terms of access: it must ensure that no-one with the capacities to succeed in higher education is barred from doing so" (DoE 1996:2).

These proposals formed the 76-section Higher Education White Paper that was introduced in January 1997 (RSA 1997b), which a Parliamentary Portfolio Committee rectified into 77 sections that later became the Higher Education Policy Act 101 of $19^{\text {th }}$ December 1997.

\section{The Policy Provisions}

HEP 101's 77 sectional provisions encompass 9 chapters of the 46-page policy document. Sections 1-3 are covered in chapter 1, 4-19 in chapter 2, 20-25 in chapter 3, and 26-38 in chapter 4. Chapter 5 covers sections 39-42, chapter 6 sections 43-49, chapter 7 sections 50-64, while sections 65-70 are in chapter 8, and sections 71-77 in chapter 9 .

\subsection{Highlights of HEP 101's Provisions}

The highlights of the provisions in HEP 101 with their sectional arrangements are as follows:

\subsubsection{Establishment of Council on Higher Education (CHE)}

The policy provides for the establishment of CHE in section 4, with its functions stipulated under subsections 1-5 of section 5 in chapter 2 . While section 6 obliges "every national and provincial department of state, every public funded science, research and professional council and every higher education institution" in South Africa to "provide the CHE with such information as [it] may reasonably require" for its performance; sections 8-14 specify its compositions, terms, the vacation and filling of its offices at both the executive and committee levels, for which meetings and funding (with remunerations) arrangements are provided in sections 15-17, with aspects of quality assurance promotion, and annual reports of the Council detailed in sections 7 and 18-19 of the policy.

\subsubsection{Guidelines for Establishment and Governance of Public Higher Education Institutions}

Section 20 vests the power to establishing public HEIs on the minister of Higher Education and Training (20.1) and the Parliament (20.2). Upon establishment, such institution will be declared "[a subdivision of] a university, technikon or college" by the minister after due consultation with CHE (21.1a-b), both of whom still exercise jurisdictions to either coalesce the HEIs (23.1a-e) or close them (25.1-3). The governance of HEIs is the subject-matter in chapter 4 . According to section 26 of the policy, such governance may be through an appointed "chancellor as [a] titular head" (26.1). Moreover, "every public higher education institution must establish ... a [governing] council" (26.2a), "a senate" (26.2b), "a principal" (26.2c), "a vice-principal" (26.2d), "a students" representative council" (SRC) (26.2e), "an institutional forum and such other structures and offices as may be determined by the institutional statute" ( $26.2 \mathrm{f}-\mathrm{g})$. The governing council (with consent of the senate and subject to ministerial determination) is obliged to, among other things, "determine the language policy" of the HEI (27.2), and "provide for a suitable structure ... for student support services" upon consultation with SRC (27.3). It may also "make - an institutional statute ... and ... rules" (32.1a-b) which - subject to ministerial approval (33.1) - are for governing the overall aspects of the HEI, including students' "disciplinary measures" (36) especially "after consultation with the senate and the [SRC]" (32.2d). Aspect of admission is in section 37, where the governing council (consulting with the senate) "determines the admission policy" (37.1) that "must provide appropriate measures for the redress of past inequalities and ... not unfairly discriminate in any way" (37.3).

\subsubsection{Funding and Assessment of Public Higher Education}

Section 39 (chapter 5) requires the minister (consulting with CHE) to "determine the policy on funding of public higher education which must include appropriate measures for the redress of past inequalities" (39.1), and "allocate public funds to public higher education on a fair and transparent basis" (39.2). Section 43.1 requires the CHE to "appoint an independent assessment panel" from where "an assessor who is independent ... to the public [HEI] concerned" may be appointed by the minister "to conduct an investigation at the ... [HEI]" (44.1). The investigation 
could be based on request by the governing council (45.a) or due to "financial" or "serious" circumstances (45.bi-ii), or due to council's failure "to resolve such circumstances" (45.c) or just "in the interest of higher education in an open and democratic society" (45.d).

\subsubsection{Guidelines for Establishment of Private Higher Education Institutions}

Section 53 gives any applicant who is: "financially capable of satisfying ... obligations [of higher education] to prospective students (53.1a), who can "maintain acceptable standards that are not inferior to standards at a comparable public [HEI] (53.1bi), and "comply with the requirements of the appropriate quality assurance body accredited by SAQA" (53.1bii) as well as "any other reasonable requirement determined by the registrar", the right to establish a private HEI. Such applicant should submit "an application for registration of [the] private higher education institution ... to the registrar" of private HEIs (52) - an employee designated by the Director-General of DHET in line with section 50 subsections 1-3 of the policy. Upon successful registration (54.1-2ai-iv) or conditional registration (54.3-6), the registrar has jurisdictions to certify the private HEI (55.1), provide its information to "any person" for inspection $(65.2,1)$, access its audit reports of "financial statements [and] any additional information, particulars and documents" (57.2b-c), amend its registration (58a-b) in line with section 59.3ai, or even "cancel [its] registration or conditional registration [(62.1)] in terms of [section 63]" of HEP Act.

\subsubsection{Miscellaneous Provisions in HEP Act 101}

The remainders of chapters 8 and 9 deal on sundry aspects of higher education (institutions), including the renaming of HEIs (65.1-2), offences of unauthorised provision of higher education qualifications (66.1a-b) impersonation and/or misrepresentation (66.1c; 66.2). Others are aspects of HEIs' operational liability (67), ministerial delegation or regulations of power $(68.1-2 ; 69 a-b)$, as well as issues of co-applicability of other conflicting or consistent laws with HEP Act - which sections 70 and 71 rightly resolve:

"This Act prevails over any other law dealing with higher education other than the Constitution....

Existing statute and rules of a public [HEI] in force at the commencement of this Act continue to apply to the extent that such statute and rules are consistent with this Act".

While pre-existing technikons and (private) universities are re-accorded a founding status by subsections 1 and 2 of section 72, their service conditions and benefits as well as governing councils, senates and forums are re-invented under subsections 3 and 4 .

\section{Provisional Amendments to HEP Act 101}

HEP 101 has undergone 10 legislative amendments since operational in 1997. These amendments, which attempt to either substitute or supplement the policy's sectional provisions, include Amendment Act 55 of 1999, Act 54 of 2000, Act 23 of 2001, and Act 63 of 2002. Others are Act 38 of 2003, Act 39 of 2008, Act 26 of 2010, Act 21 of 2011, Act 23 of 2012 and Act 9 of 2016. These are in addition to numerous supplementary policies, statutory provisions and institutional statutes which stem from HEP 101; like the Distance Education policy of 2014 "in terms of section 3" of HEP 101 (see DHET 2014). Highlights of these amendments and the sectional provisions affected are encapsulated in the table below. 
Table 1. HEP Amendments

\begin{tabular}{|c|c|c|}
\hline HEP Amendment & Date of promulgation & Sectional Provisions affected \\
\hline Act 55 of 1999 & $19^{\text {th }}$ December 1999 & $\begin{array}{l}\text { Sections } 1,19,26,39,40,50,53 \text {, } \\
68 \text {, and } 76 \text { were amended while } \\
\text { section } 41 \mathrm{~A} \text { was inserted. }\end{array}$ \\
\hline Act 54 of 2000 & $22^{\text {nd }}$ November 2000 & $\begin{array}{l}\text { Sections } 1,3,11,40,41,51,53,54 \text {, } \\
65,66,68, \text { and } 76 \text { were all } \\
\text { (re)amended. }\end{array}$ \\
\hline Act 23 of 2001 & $2^{\text {nd }}$ November 2001 & $\begin{array}{l}\text { Sections } 7,8,17,20,21,23,26-29 \text {, } \\
31,32,35,36,41 \mathrm{~A}, 53-55,58-60 \text {, } \\
62,64 \text {, and } 72 \text { were (re)amended; } \\
\text { sections } 65 \mathrm{~A}, 65 \mathrm{~B} \text {, and } 65 \mathrm{C} \text { were } \\
\text { inserted; while sections } 26-28 \text {, and a } \\
\text { host of other Laws in the Schedule } \\
\text { (RSA 2001:12-17) were repealed. }\end{array}$ \\
\hline
\end{tabular}

Act 63 of $2002 \quad 19^{\text {th }}$ December 2002 Sections $1,8,20,21,23,24,27,31$, 40, 41, 41A, 65A, and 69 were (re)amended with a host of new subsections inserted.

Act 38 of $2003 \quad 15^{\text {th }}$ December $2003 \quad$ Sections 5 and 24 were (re)amended while sections 38A-I were inserted.

Act 39 of 2008

$27^{\text {th }}$ November 2008

Act 26 of 2010

$7^{\text {th }}$ December 2010

Act 21 of 2011

$14^{\text {th }}$ December 2011

Act 23 of 2012
Sections 1, 5, 7, 8, 53, and 69 were (re)amended with (new) paragraphs and subsections inserted thereto.

Sections 1 and 51 were (re)amended while a new section 65D was inserted. The integration of sections 1, 26G and 3, of Skills Development Act 97 of 1998 as amended, alongside section 1 of National Student Financial Aid Scheme (NSFAS) Act 56 of 1999 as amended. Sections 1, 3, 8, 9, 13, 14, 27 , and substitution of "long title" of NQF Act 67 of 2008.

Sections 27, 34, and 47 were (re)amended with new paragraphs and subsections inserted. New sections 4A, 4B and a whole chapter 2A (sections 17A-17D) for NSFAS Act 56 of 1999, were also inserted. Section 23 of NSFAS Act 56 was however repealed through this Act.
Highlights of Amendment

New provisions on

administrative governance of HEIs through section 41A

Ministerial regulation of HEIs is reinforced through the (re)amended provisions.

New provisions on the seat of HEIs and (honorary) awards of certificates, diplomas, degrees, masters and PhDs.

New provisions on the size of HEIs governing councils and their ministerial regulation.

Provisions on "regular reporting" of the state of higher education by $\mathrm{CHE}$, and for "consequential changes" which HEIs' incorporation has on staff and student affairs.

To make HEP "consistent" with the National Qualifications Framework (NQF) Act 67 of 2008 (see RSA 2008:2).

First trans-ministerial coalesce of other policies with HEP is achieved by this Act.

Provisions on business engagements within HEIs' councils, committees and staff, and on administration of NSFAS

New provisions for the functions, management and closure of National Institute for 
were inserted. Section 13 of NQF Act 67 was also amended.

Act 9 of 2016

$17^{\text {th }}$ January and $22^{\text {nd }}$ September 2017
Sections 1-3, 7, 20, 21, 23, 27, 31, 34, 44, 45, 45A, 45B, 47, 49, 49A, 49B, 49D, 50, 51, 53, 54, 57, 65B, 65D, 66, 68, 69, were (re)amended with a new heading inserted to section 41 and the heading of section 42 deleted. Sections 38A-380, 41A, 42, and 70 were repealed while new sections 49BA, 49F-J, chapter 6A (sections 49K-49W), 65AB, 65BA, were inserted.
Higher Education, with an amendment on SAQA's annual reporting.

Provisions for a new typology of HEIs with their oversight mechanisms and conversion; as well as the articulation of prior learning framework into higher education system.

\section{Prologue to HEP's Silver-Jubilee (1997-2022)}

The above provisional amendments testify to the enduring veracity of HEP 101 in using government's redress strategy to equalise higher educational access and resources for all South Africans. They explicitly depict the success HEP 101 has achieved in circulating higher education through conciliation of past imbalances under a unified system that gives South African HEIs continual edge among African HEIs at global rankings (see Collier 2021).

However, critical aspects of education culturization and content enrichment require serious policy attention. Remarkably, the Presidency (2019) observes this in the 25-year review of the country's democracy, when it identifies recurrent students" "revolutions" as a "call for ... attention [on] the type of education ... and qualifications provided to young people" in South Africa (Presidency 2019:12b). But despite agreeing on "entrepreneurship" as a "growth [and] development" enabler, the term itself neither appears in HEP 101 nor in any of its Amendments. This is whilst countries like U.S., India and others have advanced to introducing latest entrepreneurial curriculums into their higher education systems. According to sections 803a,c (subsections 1 \& 2) of United States' HEP, all academic programmes and materials are currently expanded to "provide ... high-growth ... entrepreneurial training" for students, while HEIs are mandated to coalesce "degree ... offerings [to meet] business and industry ... needs" of current administration (United States 2021:853-854). Latest Amendments to India's education policy, on the other hand, specify educational content culturization "as per local contexts and needs" (section 4.31), making "entrepreneurship" a "requisite national and local [curricular] material" taught in "own pedagogical styles" to promote local knowledge, technological development and "creativity of ... student entrepreneurs" (India 2020:17,21,56).

\section{Discussions: Towards HEP 101's first Didactic Amendment?}

Higher education in post-Apartheid South Africa has evolved through periods of democratized access, didactic throughputs and the present period with concerns for the curriculum (Lange 2017:35-50). The historic need for equitable access to higher education justified the hitherto "redress" strategy that triggered the expansion of labour supply beyond its demand, thereby prompting questions on the pedagogies. Contemporary socioeconomic challenges which threaten the quality and efficacy of higher education in South Africa, however, signify that HEP 101's "redress" strategy may be due for a comprehensive review in its quarter-century operation (Adonis \& Silinda 2021:75). These challenges are manifest in growing socioeconomic predicaments exacerbated by the pandemic, which portend the urgency of suitable answers to the curricular concerns. Hence, government cannot remain in denial of the challenges of economic self-reliance experienced by graduates. A fervent political is required for an interventionist strategy that buttresses economic freedom for all students through curricular improvement. In this regard - and drawing from the experience of nations within and outside the continent, we argue in favour of entrepreneurship pedagogy, as having the right answer to the curricular concerns currently expressed in South Africa.

This opinion is consonant with international best policy practices as obtainable even in the continent. Countries like Kenya, Nigeria and others, have since aligned with this strategy in pursuance of their national development aspirations. One of the core guiding principles of Kenyan higher education as enshrined in section 4.r of the policy, is the "promotion of ... an entrepreneurial culture" (Kenya 2013:226), prompting the incorporation of "entrepreneurial education ... into undergraduate courses in universities, colleges and tertiary institutions" (Mwanzu 
\& Wendo 2021:6). Kahando and Mungai (2018) earlier found that this strategy is effective even amongst students in different academic background: "the introduction of entrepreneurship education as a compulsory course among engineering students ... strongly influenced [their] self-employment intention ... in Kenya" (Kahando \& Mungai 2018:30). Nigeria's journey with compulsory entrepreneurship pedagogy, on the other hand, began since 2006 when "Government decided to introduce ... Entrepreneurship Module into the curriculum of all universities" (Meng et al 2019:1). Section 81.c of the amended National Policy on Education stipulates "entrepreneurship" (FGN 2013:39) as a mandatory module for "all categories of students notwithstanding their area of specialisation" (Ubogu 2020:128), while section 82.d specifies "entrepreneurial skills acquisition [as] a requirement for all Nigerian universities" (FRN 2014:42). South Africa could draw insights from above country-examples and replicate their success stories using Albert Bandura's (1971) social learning theoretical framework.

\section{Conclusion}

Some of the swiftest transformations that democratic South Africa has experienced, is in the sector of (higher) education. Impairing deficiencies of the past system have practically been superseded to an extent that only requires strategic consolidation of democratic gains through sensible policy adjustment, to obviate probable failure by current system. In its twenty-four-year mission, HEP 101 has advanced unlimited circulation of higher education under a unified government control thereby ensuring a decent context for higher education with soft playground for all South Africans through conciliation. However, in areas of educational culturation (adapting to/ reflecting indigenous culture), coalescence (blending with latest societal needs), and content upgrade (pedagogic enrichment), very little perhaps nothing - is specified under current policy framework.

\subsection{Post-Script}

Whereas HEP 101 may have realised most of its founding goals, it is apparent that South Africa has not reached the 'promise-land' of economic freedom for the teaming unemployed graduates. The volatile state in HEIs and the society, occasioned by incessant disputes and destructive protests, testify to the fact that a lot needs to be done to achieve institutional and societal stability in the country. Worse still, the heightening spate of joblessness among the working-age population (Stats SA 2021:13) several of whom possess certain professional/ educational qualifications, calls for urgent policy intervention to diversify economic empowerment far beyond the traditional white-collar jobbing spectrum. DHET could, therefore, initiate further amendment(s) to HEP 101 by inserting new section(s) to effect 'educational content improvement' that officially augments students' capacity towards economic independence. This is congruent with HEP's principles of promoting "full realisation of the potential of every student [in] appreciation of diversity" and in response to "the needs of the Republic and of the communities served by the institutions" (RSA 1997a:2). It is also consistent with the principle of "freedom and autonomy" (for HEIs) - but in this wise, economic freedom and independence for the students. Ultimately, the Department could reiterate extant government's economic restructuring strategy into higher education sector, to formulate a new higher education masterplan in commemoration of HEP 101's silver-jubilee - whose foremost principle still entails restructuring and transforming programmes and institutions to respond better to the human resource, economic and development needs of the Republic" (RSA 1997a:2).

\section{References}

Adonis, C. K., \& Silinda, F. (2021). Institutional culture and transformation in higher education in post-1994 South Africa: a critical race theory analysis. Critical African Studies, 13(1), 73-94. https://doi.org/10.1080/21681392.2021.1911448

Bandura, A. (1971). Social Learning Theory. New York City 10016: General Learning Press.

Collier, S. (2021). "Top Universities in Africa" TopUniversities.com $4^{\text {th }}$ August 2021. Retrieved 05/09/2021 at $11.46 \mathrm{am}$ from https://www.topuniversities.com/university-rankings-articles/world-university-rankings/top-universities-africa

DHET. (2014). Policy for the provision of Distance Education in South African universities. Pretoria: Department of Higher Education and Training.

DoE. (1996). Green Paper on Higher Education Transformation. Pretoria: Department of Education, Republic of South Africa.

FGN. (2014). National Policy on Education (6 $6^{\text {th }}$ Ed.). Lagos: Nigerian Education Research and Development Council.

India (2020). National Education Policy 2020. New Delhi: Ministry of Human Resource Development. 
Kahando, D. M., \& Mungai, E. N. (2018). Influence of Cognitive Factors on Self-Employment Intention Among Students in Technical, Vocational Education and Training in Kenya. International Journal of Business Administration, 9(5), 21-32. https://doi.org/10.5430/ijba.v9n5p21

Kenya. (2013). Education Act No. 14, 2013. Nairobi: Department of Education.

Lange, L. (2017). 20 Years of higher education curriculum policy in South Africa. Journal of Education (University of KwaZulu-Natal), (68), 31-57.

Meng, L., Declan, S., \& Chukwuma-Nwuba, E. O. (2019). Entrepreneurship Education in Nigerian University and Its Influence on Graduate Intention. http://repository.falmouth.ac.uk/3414/1/Entrepreneurship\%20Education.pdf

Mwanzu, A., \& Wendo, D. R. (2021). Developing Entrepreneurial Potential in Information Science Students: A Critical Review of LIS Training Programs in Kenya. Library Philosophy and Practice (e-journal), 5267.

Presidency. (2019). Towards a 25-year Review (1994-2019). Pretoria: Government Press.

RSA. (1997a). Higher Education Act, 1997. Government Gazette, 390(18515), 1-24.

RSA. (1997b). Higher Education Bill (As Introduced). Government White Paper w75-97, 1-25.

RSA. (1999). Higher Education Amendment Act 55. Government Gazette, 413(20651), 1-6.

RSA. (2000). Higher Education Amendment Act 54. Government Gazette, 425(21784), 1-10.

RSA. (2001). Higher Education Amendment Act 23. Government Gazette, 22808(1104), 1-17.

RSA. (2002). Higher Education Amendment Act 63. Government Gazette, 450(24187), 1-14.

RSA. (2003). Higher Education Amendment Act 38. Government Gazette, 462(25840), 1-6.

RSA. (2008). Higher Education Amendment Act 39. Government Gazette, 521(31651), 1-6.

RSA. (2010). Higher Education Laws Amendment Act 26. Government Gazette, 546(33855), 1-10.

RSA. (2011). Higher Education Laws Amendment Act 21. Government Gazette, 58(34865), 1-8.

RSA. (2012). Higher Education and Training Laws Amendment Act 23. Government Gazette, 570(36022), 2-16.

RSA. (2016). Higher Education Amendment Act 9. Government Gazette, 619(40548), 1-49.

Stats SA. (2021). Quarterly Labour Force Survey: Quarter 2. Statistical Release P0211 August 24, 2021, 1-138.

Ubogu, R., (2020). Entrepreneurship Education: Challenges and Strategies towards Promoting Entrepreneurship in Higher Education in Nigeria. Academic Journal of Interdisciplinary Studies, 9(5), 125-125. https://doi.org/10.36941/ajis-2020-0091

United States. (2021). Higher Education Act of 1965 [As Amended Through P.L. 117-2, Enacted March 11, 2021 ]. Washington, DC 2020: U.S. Department of Education.

\section{Copyrights}

Copyright for this article is retained by the author(s), with first publication rights granted to the journal.

This is an open-access article distributed under the terms and conditions of the Creative Commons Attribution license (http://creativecommons.org/licenses/by/4.0/). 